\title{
ENVIRONMENTAL AND HEALTH ASPECTS OF CIS-MODULE PRODUCTION, USE AND DISPOSAL
}

\author{
Werner Thumm, Andreas Finke, Birgit Neumeier, Barbara Beck, Antonius Kettrup, \\ Institute of Ecological Chemistry, GSF, Neuherberg, Germany \\ Hartmut Steinberger, Fraunhofer Institute for Solid State Technology, Munich, Germany \\ Paul D. Moskowitz, Brookhaven National Laboratory, Upton, New York, USA \\ Robert Chapin, National Institute of Environmental Health Sciences, Research Triangle Park, North Carolina, USA
}

\begin{abstract}
Copper indium diselenide (CIS) is one of the most promising compounds in thin film technology. Since there is scant information available about environmental and health hazards, a study was initiated to characterize risks associated with the production, use and disposal of thin film photovoltaic modules. Data available from literature and developers of this technology contribute to an assessment of potential risks during production. In laboratory experiments the release of hazardous materials during operation caused by accidents or false handling and after disposal are simulated. In biological experiments the possible impact on living matter is established. These experiments comprise toxicity tests with aquatic organisms and rats representing mammals.
\end{abstract}

\section{THEORETICAL STUDIES}

The complete lifecycle of almost all products includes:

- the starting material

- the manufacturing

- the installation, operation and use

- the recycling and disposal.

Today, nearly any type of marketing concept is based on a linear product path starting with the raw material and ending after usage with the disposal of the product. However, most product life cycles can be closed by a recycling strategy based either on the product or material level.

In order to characterize all materials and materialpaths into air, water and soil in the life cycle of our selected product for the thin-film modules we define the areas of investigations according to the following:

In the production of starting materials for the thin-film modules, solids, liquids, gaseous materials (elements and compounds) and prefabricated components must be considered. Solar module manufacturing uses these materials including the substrate, thin-films, laminates, cover glass, junction boxes, cables and frame materials. For the installation, operation or use we have restricted the photovoltaic (PV) modules to power application products like solar power plants or solar houses or to public accessible products like solar powered emergency call boxes on highways. Normal operation and accidents must be examined. Disposal including landfilling and incineration are issues to be investigated with their contribution of the material and material-flows of the products and byproducts into the environment e.g. drain-water, decomposition gas, slag or electro-filter dust and exhaust fume.

The principal material flow of input, output and auxiliary substances in a single processing step is shown in Fig. 1. Input materials are all materials partly or totally transformed into the product. Auxiliary materials are all materials taking part in the processing but not remaining in the product. Output materials are the rejected input materials or the rejected auxiliary materials [1].

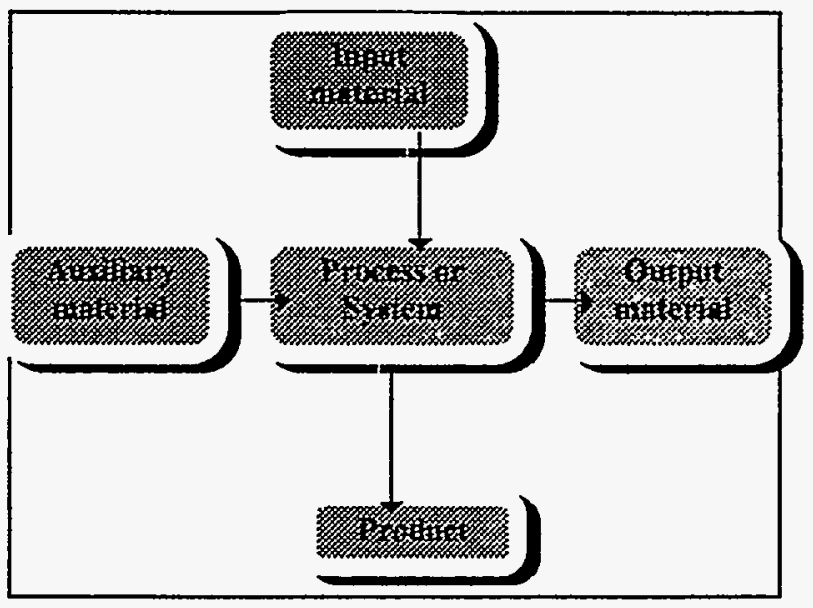

Fig. 1. Definition of input, output, auxiliary materials

\section{Starting materials}

The weight ratio of an element within the uppermost shell of the earth is called the total abundance. In order

This research was performed under the auspices of the United States Department of Energy under Contract 
to identify the highest need for the conservation of resources Table 1 compares total material abundance, annual production rate, and minimum material consumption of important materials needed to produce one $\mathrm{GW}_{e}$ of solar modules. This roughly correlates to a $10 \mathrm{~km}^{2}$ module area. Based on this analysis, it seems that indium (In) and selenium $(\mathrm{Se})$ will be the bottleneck materials in future.

\begin{tabular}{|l|c|c|c|}
\hline \multicolumn{1}{|c|}{ Material } & $\begin{array}{c}\text { Abun- } \\
\text { dance }\end{array}$ & $\begin{array}{c}\text { Produc- } \\
\text { tion t/a }\end{array}$ & $\begin{array}{c}\text { Consump- } \\
\text { tion } \text { tGW }\end{array}$ \\
\hline \hline copper & $1 \cdot 10^{-4}$ & $9,300,000$ & 1100 \\
\hline indium & $1 \cdot 10^{-7}$ & 134 & 30 \\
\hline selenium & $8 \cdot 10^{-7}$ & 1,500 & 41 \\
\hline cadmium & $3 \cdot 10^{-5}$ & 18,000 & 3 \\
\hline molybdenum & $1 \cdot 10^{-5}$ & 117,000 & 76 \\
\hline soda lime glass & $1 \cdot 10^{-1}$ & $21,000,000$ & 125,000 \\
\hline
\end{tabular}

Table 1. Abundance, production and material consumption of important elements for thin-film module fabrication

\section{Manufacturing}

For a CIS module the total material input of the critical element $\mathrm{Cd}$ is calculated for a $1 \mathrm{~m}^{2}$ module area and a $1 \mu \mathrm{m}$ layer thickness. CIS consumes roughly $1 \mathrm{~g} / \mathrm{m}^{2} / \mathrm{\mu m} \mathrm{Cd}$ for the cadmium-sulfide (CdS) layer formation as the total input material. In comparison CdTe uses 10 to $550 \mathrm{~g} / \mathrm{m}^{2} / \mu \mathrm{m} \mathrm{Cd}$ for the CdTe and CdS layer formation depending on the deposition technique.

\section{Installation, operation, use}

Several authors describe problems caused by accidents or incidents during installation [2-4]. Failures during operation due to weather and other reasons may lead to the destruction of modules which may in certain cases lead to a release of critical substances. Table 2 shows the different reasons for the failure of modules.as investigated by $\mathrm{O}^{\prime}$ Riordan [5] on the Fota Islands in Ireland.

\begin{tabular}{|l|c|c|}
\hline Reason for the problems & Numbers & $\%$ Ratio \\
\hline Broken front glasses & 22 & 28 \\
\hline Oxidation of front contacts & 16 & 20 \\
\hline $\begin{array}{l}\text { Color change of the sub- } \\
\text { strate }\end{array}$ & 15 & 19 \\
\hline Penetration of water & 11 & 14 \\
\hline Broken substrate glasses & 10 & 13 \\
\hline Broken ends & 4 & 5 \\
\hline Laminate & 1 & 1 \\
\hline In total for 2,772 modules & 79 & 100 \\
\hline
\end{tabular}

Table 2. Effects and problems of silicon solar modules on the Fota Islands in Ireland

\section{Disposal}

In Germany the "technical regulations for municipal waste" demand that any kind of waste should be pretreated before disposal. This usually implicates incineration in a municipal waste incinerator. Other industrial countries like USA also favour the treatment of waste in a comparable manner. For the final disposal of wastes (e.g. slag and filter dust) limit values are given for the content of certain elements and organic residues. The analytical tool for the determination of element content is the German leaching test DEV S4.

On the basis of a one year averaged distribution of input and output materials for a German municipal waste incineration facility [6], we have estimated the total released material in slag, filter dust and pure gas assuming a $1 \mathrm{~kW}$ module input of CIS-technology (see Fig. 2).

These estimations again take into consideration the materials both from the thin-film layers on the substrate (primary) and the frame materials (secondary). The main contribution in the case of CIS is $\mathrm{Cu}$ in the slag of around $200 \mathrm{~g}$ in total, of $43 \mathrm{~g}$ in filter dust and $4 \mathrm{~g}$ in the released gas dust. Cadmium is represented in slag as $1.5 \mathrm{~g}$, as $0.5 \mathrm{~g}$ in the filter dust, and around $0.05 \mathrm{~g}$ in the released gas dust.

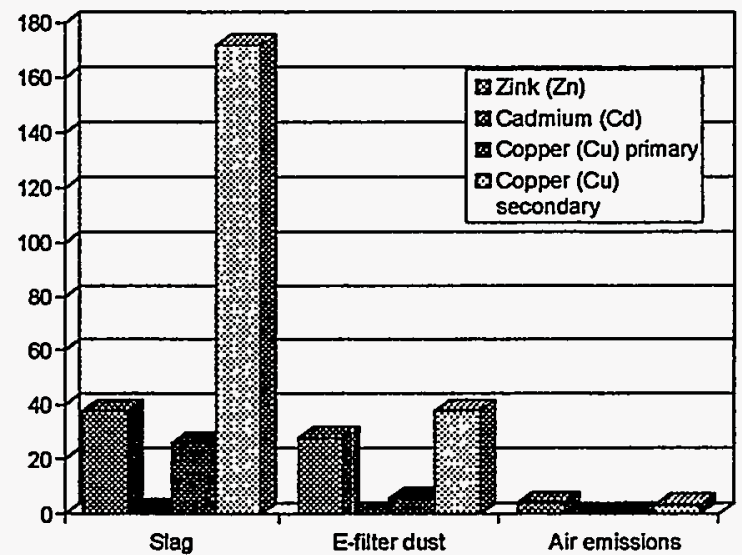

Fig. 2. Output material distribution of a $1 \mathrm{~kW}$ CIS-module input into a municipal waste incineration facility in Germany

\section{Recycling}

Preexperiments on commercially available CdTe-modules for recycling have been carried out using liquid nitrogen, sand blasting techniques and $\mathrm{HCl}$ etching. Liquid nitrogen has peeled off large areas of thin-film layers. The remaining residues on the surface of the glass substrate were then etched back by $\mathrm{HCl}$, which left a clean transparent glass substrate showing small reflecting zones along the removed structuring lines. Sand blasting with different particle sizes seems also possible for re- 


\section{DISCLAIMER}

Portions of this document may be illegible in electronic image products. Images are produced from the best available original document. 
cycling, if the working speed can be controlled to avoid surface cracks or holes of the glass substrate. Similar studies are being prepared for CIS modules.

\section{EXPERIMENTAL WORK}

\section{Leaching tests}

The leaching of substances from modules broken by accident or disposal in a landifll is simulated by na-tionally and internationally approved elution tests and in outdoor experiments. The outdoor tests started in 1992 and will be finished by the end of 1994 [6].

For the elution tests four different methods are used: The German DEV S4 (Deutsches Einheitsverfahren), the US TCLP (Toxicity Characteristics Leaching Procedure), the Swiss leaching test and a test developed by the University of Wisconsin for EPA. They have in common that fragmented samples are rotated end over end for a certain time period (usually $24 \mathrm{~h}$; TCLP $18 \mathrm{~h}$ ) with an eluent.

In Fig. 3 a part of the results with these tests is shown. $\mathrm{Zn}, \mathrm{Mo}$ (molybdenum) and $\mathrm{Se}$ are the elements eluted in the highest amounts from CIS-modules. Mo and $\mathrm{Se}$ are supposed to elute as anionic species and this may explain their elution behavior at rather high $\mathrm{pH} . \mathrm{Zn}$ concentrations increase with decreasing $\mathrm{pH}$ and increasing complexing agent content.

leaching rato (nol)

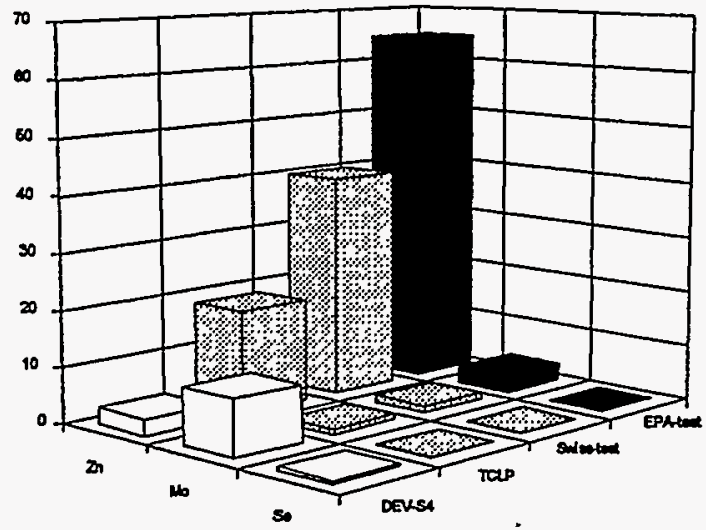

Fig. 3. Element concentration in the eluate of DEV S4, TCLP, EPA and Swiss test

With respect to element concentrations the limit values in Germany for a landfill class $/ 1$ are $5 \mathrm{mg} / \mathrm{ln}$ (found $2.8 \mathrm{mg} / \mathrm{l}) ; 1 \mathrm{mg} / \mathrm{l} \mathrm{Cu}$ (found $15 \mu \mathrm{g} / \mathrm{l}$ ) and $50 \mu \mathrm{g} / \mathrm{Cd}$ (found $28 \mu \mathrm{g} / \mathrm{l}$ ). In the US only Se and $\mathrm{Cd}$ are regulated to $1 \mathrm{mg} / \mathrm{l}$ (found $60 \mu \mathrm{g} / \mathrm{l}$ Se and $31 \mu \mathrm{g} / \mathrm{l} \mathrm{Cd}$ ) with respect to the TCLP. If only related to metal the tested modules would nase hoth_tastc.

\section{DISCLAIMER}

\section{Thermal testing}

Fig. 4 shows the results of a differential thermal analysis. Samples of pure CIS material were heated in air. Important information can be deduced from the thermogravimetry curve. For CIS, a weight loss of $27 \%$ is found starting at $300{ }^{\circ} \mathrm{C}$. This corresponds to the replacement of the entire Se by oxygen $(O)$ and the release of selenium dioxide $\left(\mathrm{SeO}_{2}\right)$.

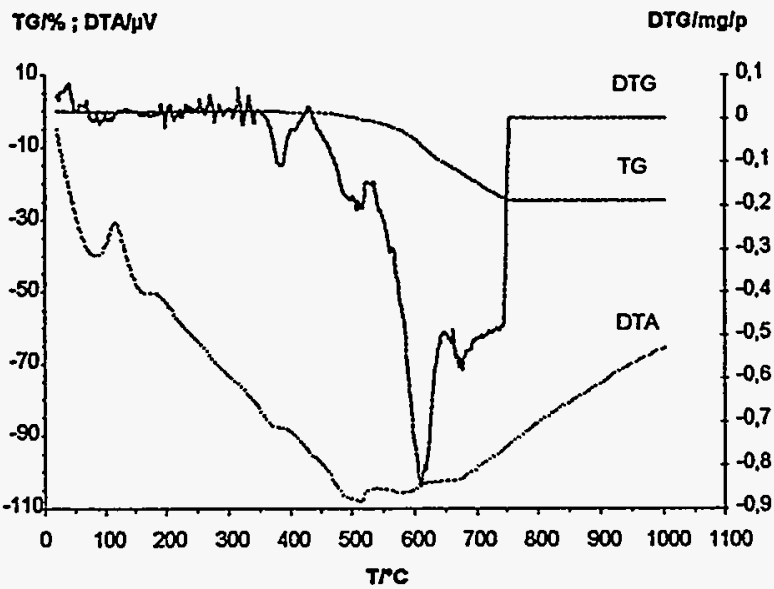

Fig. 4. Differential thermal gravimetry (DTG), thermal gravimetry (TG), differential thermal analysis (DTA) of pure CIS material in air

\section{Sorption tests}

In the sorption experiments with soils and clay minerals, usually a strong sorption is found for cationic species, whereas the sorption for anionic species like molybdate is rather faint (see Fig. 5). For $\mathrm{Se}$ in its two possible anionic species, the situation becomes more difficult, because selenite is a strong adsorbent in contrast to selenate which usually is a weak one.

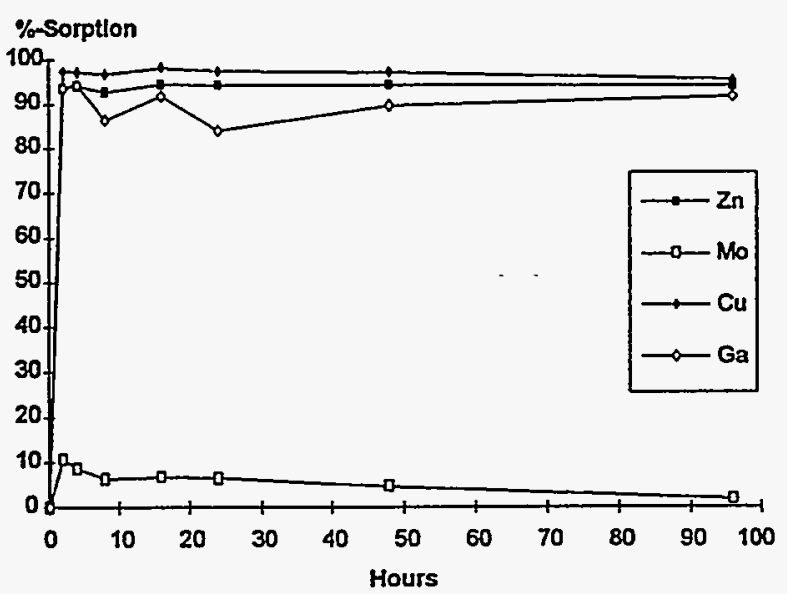

Fig. 5. Sorption tests with standard soil for CIS material

This report was prepared as an account of work sponsored by an agency of the United States Government. Neither the United States Government nor any agency thereof, nor any of their employees, makes any warranty, express or implied, or assumes any legal liability or responsibility for the accuracy, completeness, or usefulness of any information, apparatus, product, or process disclosed, or represents that its use would not infringe privately owned rights. Reference herein to any specific commercial product, process, or service by trade name, trademark, manufacturer, or otherwise does not necessarily constitute or imply its endorsement, recommendation, or favoring by the United States Government or any agency thereof. The views and opinions of authors expressed herein do not necessarily state or reflect those of the United States Government or any agency thereof. 


\section{Toxicity tests with daphnia and algae}

In toxicity tests, the effects found were dependent on the speciation of the single elements tested. That means, the oxidation state as well as the counterions influence toxicity. This effect is demonstrated in Table 3 for toxicity tests with daphnia magna (waterflea) for Se. The same effect can be observed in other toxicity tests.

\begin{tabular}{|l|c|c|}
\hline Test substance & $\begin{array}{c}\text { EC50 } \\
\text { (mg/l of element) }\end{array}$ & element \\
\hline \hline $\mathrm{CuSO}_{4}$ & 0.02 & $\mathrm{Cu}$ \\
\hline $\mathrm{Na}_{2} \mathrm{SeO}_{4}$ & 2.2 & $\mathrm{Se}$ \\
\hline $\mathrm{Na}_{2} \mathrm{SeO}_{3}$ & 3.7 & $\mathrm{Se}$ \\
\hline $\mathrm{ZnSO}_{4}$ & 1.7 & $\mathrm{Zn}$ \\
\hline
\end{tabular}

Table 3. Daphnia magna - acute toxicity (24h-Test)

Fig. 6 shows the result of an acute toxicity test with algae for sodium selenate. Selenium in its different speciations shows a non-classical behavior in some toxicity tests; at rather low concentrations, no toxic action can be detected, but a small stimulating effect can be observed.

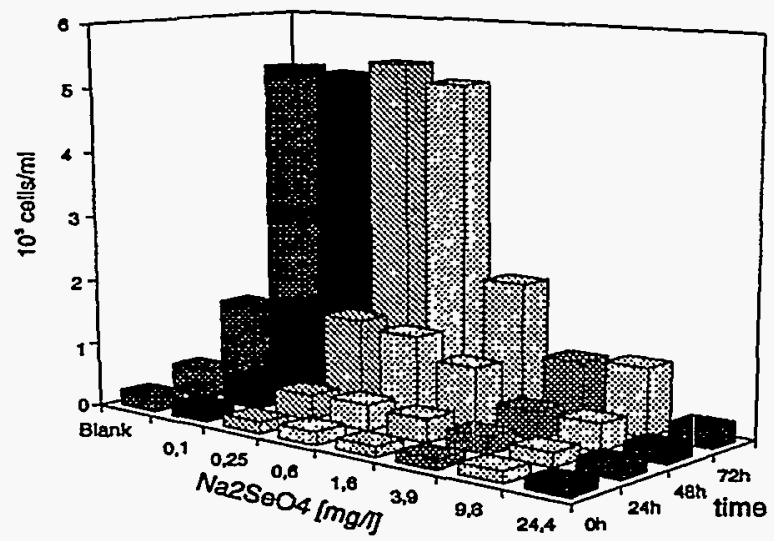

Fig. 6. Acute toxicity on algae

For future experimental work, it will be necessary to focus more on the speciation of the elements that are able to enter the environment, because the impact and the effect of these elements on compartments of the environment greatly depends on their speciation. Combinatory effects of compounds that may come into existence from solar cells also have to be taken into account.

\section{Rat studies}

To determine the toxicity of the thin-film materials of the PV modules, a short term toxicity study was undertaken using rats as the model species. First, a pilot study was performed to set doses for the main study. The main study evaluated a number of endpoints of systemic toxicity, as well as potential reproductive and developmental effects [8].
Groups of mature male and female Sprague-Dawley rats were administered an aqueous suspension of $\mathrm{CIS}$ in $0.5 \%$ methylcellulose by gavage at levels of $0,50,100$, and $250 \mathrm{mg} / \mathrm{kg}$ of body weight.

The different groups were investigated with respect to histopathology, hematology, fertility and reproduction. Even at high doses no or only small effects were detected.

From the range finding studies with rats reference doses for man were derived from the lowest observed adverse effect level (LOAEL) using appropriate uncertainty factors. The LOAEL for CIS of $250 \mathrm{mg} / \mathrm{kg}$ rat $/$ day results in a reference dose for man of $8.3 \mu \mathrm{g} / \mathrm{kg} /$ day. This means a daily uptake of a $70 \mathrm{~kg}$ man of $0.58 \mathrm{mg}$ CIS is not expected to be harmful.

\section{ACKNOWLEDGEMENT}

This study is funded by the German Bundesministerium für Forschung und Technologie (BMFT). The rat studies were funded in parallel by the US Department of Energy (DOE) and the National Institute of Environmental Health Sciences (NIEHS).

\section{LITERATURE}

[1] Steinberger, Environmental and health aspects of Copper-indium-diselenide and Cadmium-telluride thin film Photovoltaic modules, CIS, CGS, and CdTe Photovoltaic NREL-workshop report, Denver 1994.

[2] van der Weiden, et al., PV/Diesel systems on house boats, Tenth EC Photovoltaic Energy Conference, Lisboa 1991

[3] Schaffrin, The solar boat "KORONA": Two years of experience , Tenth EC Photovoltaic Energy Conference, Lisboa 1991

[4] Chianese, et al., Tiso: 4-kW experimental amorphous silicon PV-plant, Tenth EC Photovoltaic Energy Conference, Lisboa 1991

[5] O'Riordan et al., Detailed analysis of a photovoltaic project after 7 years of operation, Tenth EC Photovoltaic Energy Conference, Lisboa 1991.

[6] Nottrodt, Die festen Verbrennungsrūckstände, MüllHandbuch, Loseblattsammlung, Band 4, $38 \mathrm{Lfg} \mathrm{XI/75,}$ Berlin, 1975.

[7] Thumm, et al. Experimental approach to asses environmental risks of thin-film solar cells, CIS, CGS, and CdTe Photovoltaic NAEL-workshop report, Denver 1994.

[8] Chapin, et al. The general and reproductive toxicity of the Photovoltaic material Copper-indium-diselenide, CIS, CGS, and CdTe Photovoltaic NREL-workshop report, Denver 1994. 